\title{
Effects of Soil Texture on Vegetative and Root Growth of Senna obtusifolia seedlings indigenous to Bichi, Sudan savannah of Northern Nigeria, in Green House Conditions
}

\author{
Abdulazeez, A \\ (Department of Agricultural Education, Federal College of Education (Technical) Bichi, Nigeria.
}

\begin{abstract}
There is considerable disagreement on the natural soil requirement for sufficient growth and development of Senna obtusifolia. Therefore, green house grown trials of Senna obtusifolia seedlings in five different soils were investigated. Viable seeds of the Senna obtusifolia were sown in clay, clay sand, loam, loam sand and sandy soils and the germinated seedlings were monitored for a period of eighteen days in a Randomized Complete Block Design (RCBD) with four replications. Several growth parameters were taken during the experimental period. Vegetative and root productions of the Senna obtusifolia seedlings grown in the poor drained and heavy clay soil significantly restricted, and therefore has to be avoided. On the contrary, well drained and rich loam soil seems ideal for vegetative production and root growth of Senna obtusifolia seedlings. Results findings indicate that Seena obtusifolia seeds can germinate and grow in all types of soils however; the plant seeds germinate and grow much better in loam soil than other soils. The results suggest loam soil for sufficient vegetative and root production of Senna obtusifolia seedlings in Bichi, Sudan Savannah of Northern Nigeria.
\end{abstract}

Keywords: green house, root, Sudan savannah, senna obtusifolia, soil texture, vegetative.

\section{Introduction}

Senna obtusifolia (L) Irwin and Barneby is commonly called sickle pod. S. obtusifolia is a native to tropical South America, but has become widespread throughout the tropics and subtropics regions of all continents, except Europe (Brenan, 1967). The plant is utilized locally for a variety of reasons, particularly as food, and medicine, and it is occasionally cultivated for these purposes. The flowers are decorative and the plant is commonly planted as an ornamental near towns (Ken, 2014). The young, tender leaves are occasionally used as a vegetable throughout Africa and elsewhere. Older leaves if eaten frequently or in large quantities will cause diarrhea. The fermented leaves can be made into a high protein food, known as 'kawal' in Sudan (Irwin and Barneby, 1982 and Becker, 1986). Roasted seeds have been used as a substitute for coffee, the leaves are used to make a tea - like infusion (Ken, 2014) and the whole dried plants have been compounded with other feed ingredients to formulate balanced Chinchilla rabbit diet (Abdulazeez, 2016). The seeds contain commercially interesting levels of gum. In India they are collected from wild plants for the industrial extraction of gums (galactomannans) for the food industry. The leaves are anthelmintic, laxative and poultice. The plant stems are used to make mats, fences and also used for firewood (Ken, 2014). The plant can spread freely and it is considered to be a weed in many parts of the world for example, an estimated 600,000 hectares of land are infested with it in Queensland (Australia) (Irwin and Barneby, 1982). Gopal (1990) defined soil as a thin layer of the earth's crust which serves as a natural medium for the growth of plants. Buckman and Brady (1960) described soil texture as the 'feel' of a soil, or as the relative proportions of sand, silt, and clay in the soil. When they are wet, sandy soils feel gritty, silt soils feel smooth and silky, and clay soils feel sticky and plastic, or capable of being moulded. Soils with a high proportion of sand are referred to as 'light', and those with a high proportion of clay are referred to as 'heavy'. The names of soil texture classes are intended to give an idea of textural make-up and physical properties of soils. The three basic groups of texture classes are sands, clays and loams. A soil in the sand group contains at least $70 \%$ by weight of sand, a soil in the clay group contains at least $35 \%-40 \%$ clay and, a loam soil is a mixture of sand, silt and clay particles that exhibit light and heavy properties in about equal proportions. The basic soil group name comes last in the class name, thus loam sand is in the sand group, and sandy loam is in the loam group (Buckman and brady, 1960). The characteristics of soil play a big part in the plant's ability to extract water and nutrients. If plants are to grow to their potential, the soil must provide a satisfactory environment for plant growth. Plants obtain oxygen and carbon from the air by photosynthesis. Soil provides the place for plants roots to anchor and grow. It holds the water in which the soil plant nutrients are changed into ions, which the form that the plant can use. It holds the air space that prevents the plant from becoming water logged; it holds the chemicals that determine soils $\mathrm{pH}$, salinity and dispersivity (CSIRO, 1979). According to Komolafe and Joy (1981), clay soil is sticky, plastic and easily mouldable in to shapes when wet. Air and water do not move easily within them. Clay particles tend to aggregate in to lumps 
Effects of Soil Texture on Vegetative and Root Growth of Senna obtusifolia seedlings indigenou...

which get very hard as they dry out. Thus clay soils are heavy to work, drain poorly, very hard for root to penetrate and seed to germinate. Clay soil is potentially rich in plant nutrients; however, because of poor drainage these nutrients are often withheld from the plants. Loamy soils are 'all round' soils and may be used to grow most crops. They have the advantages of clay soils in that they retain plant nutrients yet, they also have the drainage of sandy soils. They are easy to cultivate, easy for root plats to penetrate and ideal for seed germination. Sandy soils are well aerated, light and easy to work, they allow viable seeds to germinate easily and easy penetration of roots, but they have the disadvantages of being hungry soils, because nutrients are easily leached away by drainage. Water drains easily through sandy soils very rapidly. Regarding specific soil texture and plant development, the available information suggests that Senna obtusifolia is well adapted to wide range of types of soils. Ken (2014) reported that Senna obtusifolia prefers a deep, well-drained, moderately fertile sandy loam soils and position in full sun. Cornell University (2006) concluded that Senna obtusifolia tolerates damp soil, poor drainage and damp clay soils. It prefers rich, well-drained soil that is kept slightly moist and grows well in clay soils. From the above findings, it can be summarized that the natural soil requirements for Senna obtusifolia have not been completely defined. Therefore, there is insufficient information on the plant seedling development to any particular type of soil. For this reason, the main objective of this study was to evaluate the natural effects of different soils on the above ground-vegetative growth and below ground-root development of Senna obtusifolia seedlings native to Bichi, Sudan Savannah of Northern Nigeria, under green house conditions. The substrates selected were clay, clay sand, loam, loam sand and sandy soils.

\subsection{Materials.}

\section{Materials and Methods}

Materials used include viable senna obtusifolia seeds, transparent polythene bags, ordinary water, clay, clay sand, loam, loam sand and sandy soils and measuring plastic ruler $(30 \mathrm{~cm})$.

2.2. Experimental site and Environmental conditions

The study was carried out in February 2017, inside ventilated green house of Department of Agricultural Education (DAE), Federal College of Education (T) Bichi (F.C.E.T.B.: $8^{0} 14^{1}-12^{0} 14^{1} \mathrm{E}$ and $12^{0} 14^{1}-14^{0}$ $13^{1} \mathrm{~N}$ ). No artificial conditions were imposed. The maximum and minimum temperatures registered were $38.4^{0 \mathrm{C}}$ and $25^{\circ \mathrm{c}}$ respectively.

\subsection{Methods}

\section{Biological material}

The viable senna obtusifolia seeds harvested from the Department of Agricultural Education farm in November, 2016 were used. All the seeds were about six months old and average seed weight was $0.02 \mathrm{~g}$, the seeds were dipped in boiling water at $100^{0 \mathrm{c}}$ for 15 minutes.

\subsection{Soil characterization and analysis}

Five soil types (clay, clay sand, loam, loam sand and sandy) were selected for their textural characteristics and for being representative of the soil found in Bichi Local Government Area (Table 1 and fig.3).The soils samples were taken after ploughing at $0-15 \mathrm{~cm}$ depth. The physical and chemical properties of the soils were determined (Table 1) using standard procedures at Kappal Biotechnology Laboratory, Ibadan.

\subsection{Experimental design}

Five treatments, consisting of different soil types were evaluated: clay, clay sand, loam, loam sand and sandy). The study was carried out using a randomized complete block design, with four replicates per treatment, providing a total of twenty plot units. One seed per pot was sown into a transparent polythene bag $(12 \mathrm{~cm} \times 10 \mathrm{~cm} \times 12 \mathrm{~cm})$ which was filled with the designated soil texture. Water application was carried out with $100 \mathrm{ml}$ of ordinary water in each pot every day. Planting and germination dates were registered. Measurement of length of main stems, number of true leaf, length of main roots and number of secondary roots were recorded.

\subsection{Uprooting and measurement}

Eighteen days after germination, all the senna obtusifolia seedling-plants grown in clay, clay sand, loam, loam sand and sandy soils were gently uprooted using water at a slight pressure. Stem and root lengths were measured using plastic measuring ruler $(30 \mathrm{~cm})$, main stem/shoot length was measured as the distance between the root collar and the apical meristem. The number of true leaf and secondary roots were counted and recorded (Table 2, fig. 4).

\subsection{Statistical analysis}

Statistical analysis was performed by one-way analysis of variance (ANOVA) with multiple comparison tests $(\mathrm{P}<0.05)$ by means of Gens tat programme 5.3. 


\section{Results And Discussion}

\subsection{Physical and chemical properties of the soils used}

The results of the physical and chemical properties of the five soil textures used in the study are presented in Table 1. All the five soils were found to be slightly alkaline which should render them suitable for growing of senna obtusifolia seedlings. Loam soil had the highest Organic Matter $(3.5 \%)$ and Nitrogen $(0.17 \mathrm{~g}$ $\left.\mathrm{kg}^{-}{ }^{1}\right)$, also had the highest proportions of Phosphorous $\left(0.05 \mathrm{~g} \mathrm{~kg}^{-}{ }^{-}\right)$and Potassium $\left(0.44 \mathrm{~g} \mathrm{~kg}^{-}\right)$. Conversely, the sandy soil exhibited the lowest Organic matter $(0.4 \%)$ and other plant nutrient contents (Table 1, fig. 3 ). The clay, clay sand and loam sand soils had generally intermediate values for the above recorded properties (Table 1, fig..3)

Table 1. The physical and chemical properties of the soil textures used.

\begin{tabular}{|c|c|c|c|c|c|}
\hline Soil type & $\mathrm{C}$ & $\mathrm{L}$ & $S$ & LS & CS \\
\hline Sand (\%) & $25.2 \mathrm{e}$ & $45.0 \mathrm{~d}$ & $88.6 \mathrm{a}$ & $71.1 \mathrm{c}$ & $77.9 \mathrm{~b}$ \\
\hline Clay (\%) & $45.6 \mathrm{a}$ & $15.1 \mathrm{~b}$ & $2.3 \mathrm{~d}$ & $8.1 \mathrm{c}$ & $12.4 \mathrm{~b}$ \\
\hline Silt (\%) & $29.1 \mathrm{~b}$ & $39.5 \mathrm{a}$ & $8.7 \mathrm{~d}$ & $19.5 \mathrm{c}$ & $8.7 \mathrm{~d}$ \\
\hline pH (in H20) & $7.6 \mathrm{a}$ & $7.5 \mathrm{a}$ & $7.4 \mathrm{a}$ & $7.4 \mathrm{a}$ & $7.5 \mathrm{a}$ \\
\hline Organic matter $(\%)$ & $3.3 \mathrm{a}$ & $3.5 \mathrm{a}$ & $0.4 \mathrm{~d}$ & $0.9 \mathrm{c}$ & $1.7 \mathrm{~b}$ \\
\hline $\begin{array}{l}\text { Total Nitrogen } \\
\left(\text { g kg- }^{1}\right)\end{array}$ & $0.14 \mathrm{~b}$ & $0.17 \mathrm{a}$ & $0.03 c$ & $0.05 c$ & $0.14 b$ \\
\hline $\begin{array}{l}\text { Phosphorous } \\
\left(\text { g kg- }^{1}\right) \\
\text { Potassium }\end{array}$ & $0.04 \mathrm{a}$ & $0.05 a$ & $0.02 b$ & $0.021 b$ & $0.04 a$ \\
\hline $\begin{array}{l}\text { Potassium } \\
\left(\mathrm{g} \mathrm{kg-}^{-1}\right)\end{array}$ & $0.43 \mathrm{a}$ & $0.44 a$ & $0.13 \mathrm{~d}$ & $0.18 \mathrm{~d}$ & $0.29 \mathrm{c}$ \\
\hline $\begin{array}{l}\text { Sodrum } \\
\left(\text { ( kg- }^{1}\right) \\
\text { CEC }\end{array}$ & $0.15 \mathrm{a}$ & $0.16 a$ & $0.15 \mathrm{a}$ & $0.16 a$ & $0.15 \mathrm{a}$ \\
\hline (meq.100g- $\left.{ }^{1}\right)$ & $27 \mathrm{a}$ & $11.24 \mathrm{~b}$ & $5.2 \mathrm{c}$ & $8.5 \mathrm{c}$ & $14.6 \mathrm{~b}$ \\
\hline
\end{tabular}

$\mathrm{C}=$ Clay soil, $\mathrm{L}=$ Loam soil, $\mathrm{S}=$ Sandy soil, $\mathrm{LS}=$ Loam sand soil, $\mathrm{CS}=$ Clay sand soil.

Means within a row which do not share the same letter (s) are significantly different $(\mathrm{p}<0.05)$.

\subsection{Effect of soil textures on Senna obtusifolia seedlings above and below ground growth parameters.}

The analysis of variance showed statistical differences $(\mathrm{P}<0.05)$ in above and below growth parameters between loam and other four soil-treatments. Days to germination were shorter (3days) in all the soils except clay soil which recorded longer days (5days) to germination (Table 2). At the end of eighteen days of the study, all the soils recorded maximum number of true leaf (6 leaves) except clay soil which produced minimum number (4 leaves) of true leaf (Table 2). Senna obtusifolia seedlings grown in the loam soil produced greatest stem length $(10.9 \mathrm{~cm})$, longest root length $(18.2 \mathrm{~cm})$ and highest number of secondary roots $(21)$ as compared with others soil treatments (Table 2, figs. 1,2 and 4).

Table 2. Effects of soil textures on Mean (M) Days to seed germination (DTG), Number of true leaf (NL), Stem lengths (SL), Root lengths (RL) and Number of secondary roots (NSR) eighteen days after germination.

\begin{tabular}{|c|c|c|c|c|c|}
\hline Soil type/Texture & MDTG & MNL & $\begin{array}{l}\text { Parameters } \\
\text { MSL }(\mathrm{cm})\end{array}$ & MRL $(\mathrm{cm})$ & MNSR \\
\hline Clay & $5 \mathrm{a}$ & $4 \mathrm{a}$ & $5.6 \mathrm{~d}$ & $8.2 \mathrm{e}$ & $5 \mathrm{~d}$ \\
\hline Clay sand & $3 b$ & $6 \mathrm{~b}$ & $9.1 \mathrm{c}$ & $13.4 \mathrm{~d}$ & $11 \mathrm{c}$ \\
\hline Loam & $3 b$ & $6 \mathrm{~b}$ & $10.9 \mathrm{a}$ & $18.2 \mathrm{a}$ & $21 \mathrm{a}$ \\
\hline Loam sand & $3 b$ & $6 \mathrm{~b}$ & $9.8 \mathrm{~b}$ & $15.7 \mathrm{~b}$ & $17 \mathrm{~b}$ \\
\hline Sandy & $3 b$ & $6 \mathrm{~b}$ & $9.5 \mathrm{~b}$ & $15.2 \mathrm{c}$ & $13 \mathrm{c}$ \\
\hline
\end{tabular}

Means within a column which do not share the same letter are significantly different $(\mathrm{P}<0.05)$. 


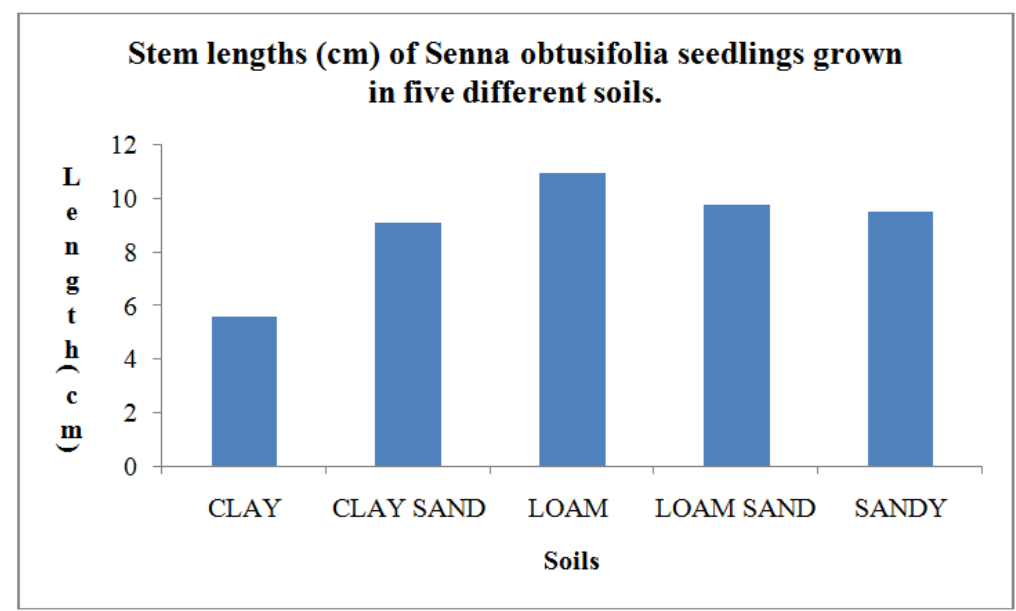

Figure 1. Stem lengths $(\mathrm{cm})$ of Senna obtusifolia seedlings grown in different soils.

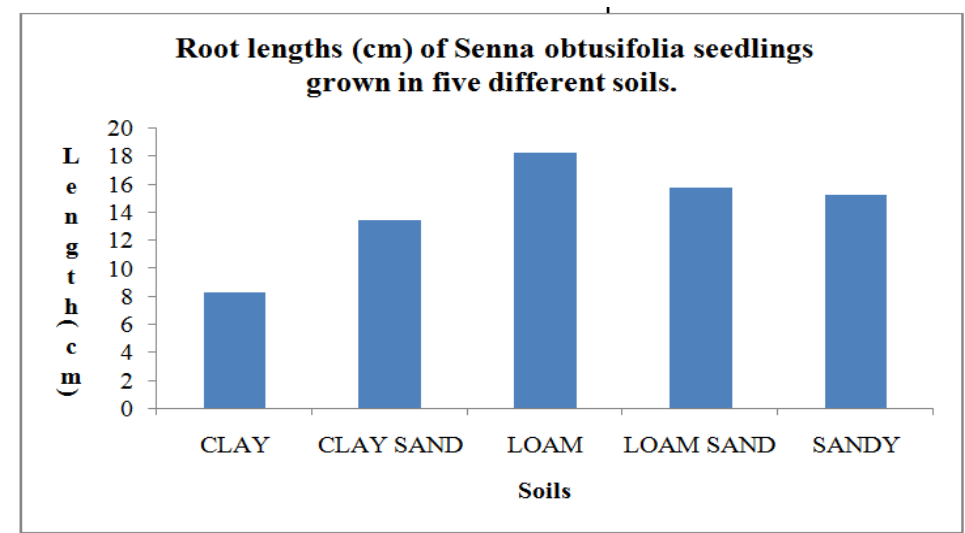

Figure 2. Root lengths (cm) of Senna obtusifolia seedlings grown in different soils.

These results concur with reports of Ken (2014), Komolafe and Joy (1981) and Cornell University (2006) regarding the preference of Senna obtusifolia plants for growth on deep, well-drained, all rounds and plant nutrients rich soil. However, the poor performance in clay soil obtained in this study is contrary to Cornell University (2006) who reported that Senna obtusifolia grows well in clay soils. The findings in this study agreed with earlier authors (Komolafe and Joy, 1981), who observed that clay soils drain poorly, heavy to work,, very hard for root to penetrate and seed to germinate and nutrients are withheld from plants

\section{Conclusion}

The available information opines that Senna obtusifolia is well adapted to wide range of type of soils, it is quite important to note that this study has demonstrated that Senna obtusifolia seedlings may not grow well in clay, clay sand and sandy soils. The results suggest that loam soil is an ideal soil for sufficient vegetative growth, root development, uniform seed germination, uniform seedlings and post seedlings management of Senna obtusifolia plants native to Bichi, Sudan Savannah of Northern Nigeria.

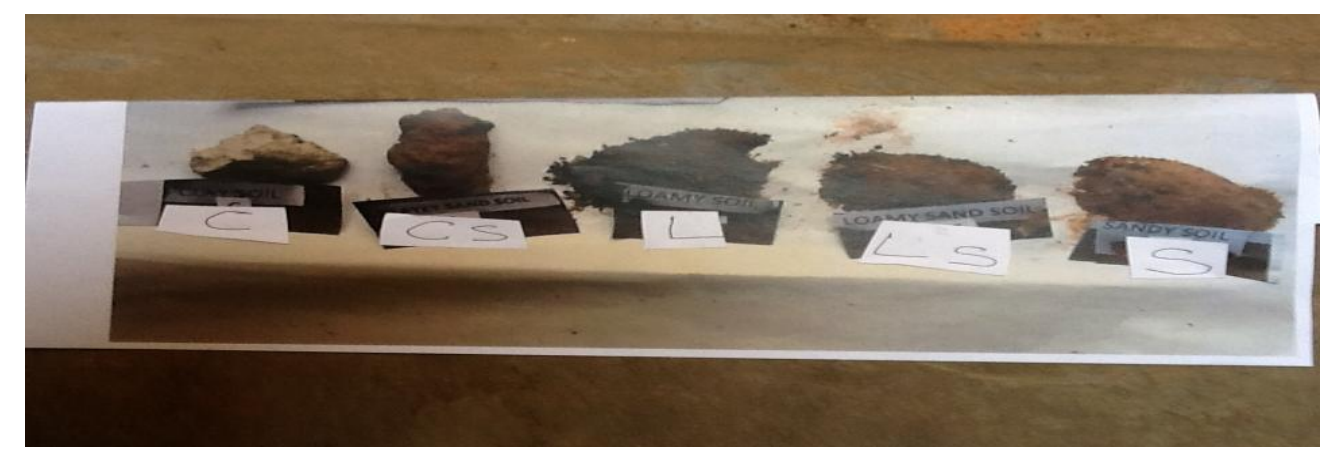

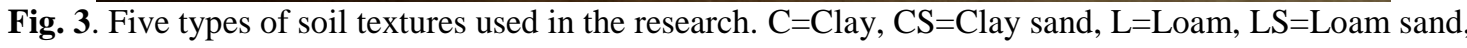
$\mathrm{S}=$ Sandy . 


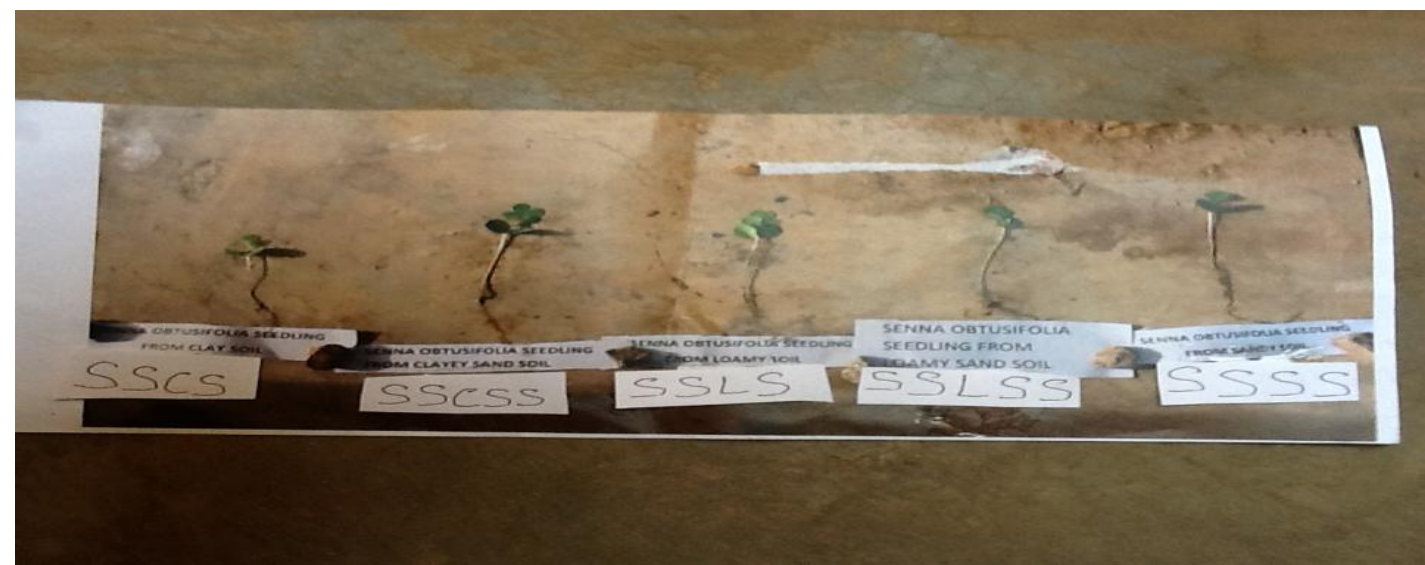

Fig. 4. Senna obtusifolia seedlings grown and harvested (above and below ground growth parameters) from the five types of soil textures used in the research study. SSCS=S.obstusifolia seedling from clay soil, SSCSS=S.obstusifolia seedling from clay sand soil, SSLS=S.obstusifolia seedling from loam soil, SSLSS=S.obstusifolia seedling from loam sand soil, SSSS=S.obstusifolia seedling from sandy soil.

\section{Acknowledgements}

I thank the soil laboratory personnel of Kappal Biotechnology Ibadan for carrying out the physical and chemical analyses of the five types of soils used in the study. I gratefully acknowledge the support provided by the green house attendants (Muasu and Adamu) of Department of Agricultural Education, Federal College of Education (Tech) Bichi, and encouragement received from Mrs, Abdulazeez, A.O.

\section{References}

[1]. Irwin H.S and Barneby R.C (1982). The American Cassiinae. Memoirs of the New York Botanical Gardens. 25:1-918

[2]. Brenan, JRM (1967). Floral of Tropical Africa. Royal Botanical gardens. UK.

[3]. Ken, F (2014). Senna obtusifolia. Useful Tropical Plants Database.

[4]. Becker, B (198 6). Wild plant for human nutrition in the Sahelian Zone of arid environments. 11(1):61-64.

[5]. Abdulazeez, A and A.O. Abdulazeez (2016). Replacement of Senna obtusifolia for Wheat offal in the diets of Chinchilla Rabbits. http://www.iosrjournals.org/iosrjavs/pages/9(4) ver.11.

[6]. Gopal, C.D.E (1990). Fundamentals of Agronomy. Institute of Agriculture. Visva-Bharati. India. Oxford and IBH Pub. Company. PTV Ltd. New Delhi.

[7]. Buckman H.O and Brady N.C (1960). The Nature and Properties of soil. https://www.amason.com/nature-propertiesof soil.

[8]. CSIRO (1979). How do properties of soils affect plant growth? http://agriculture.Vic:gov.au/agriculture/dairy/pastures.

[9]. Komolafe M.F and D.C. Joy (1981). Agricultural science for West African Schools and Colleges. University press Ltd. Ibadan. 